\title{
ANALISIS PENYUSUNAN LAPORAN KEUANGAN UMKM BATIK JUMPUT DAHLIA BERDASARKAN SAK-EMKM
}

\author{
Diajeng Amatullah Azizah Rachmanti, Misrin Hariyadi, Andrianto \\ Jurusan Akuntansi Fakultas Ekonomi \& Bisnis Universitas Muhammadiyah Surabaya
}

\begin{abstract}
The purpose of this study is to find out what the financial statements of UMKM Batik Jumput Dahlia are. Analysis of Preparation of UMKM Financial Reports Batik Grass Dahlia Based on SAK-EMKM. The type of research used is a type of qualitative research. Based on the characteristics of the problem raised by the researcher, this research is clarified as descriptive qualitative research. The data used in this study are primary data obtained directly from MSMEs such as data from interviews with MSMEs as well as data in the form of information from diaries of cash in and cash out. While for secondary data obtained from books, journals, and internet that support this research. From the results of data analysis, the results of the study show that the financial statements of UMKM Batik Jumput Dahlia present the financial positions of 2016 and 2017 as of December 31, 2016, showing total assets of IDR 15,128,300, - as of December 31, 2017 showing total assets of IDR 11,125,200 - Profit The 2016 loss was a profit of Rp 2,087,100 while the Profit and Loss of 2017 was a profit of Rp 511,000, Notes to the Financial Report (CALK) presented a general description of Batik Jumput Dahlia MSMEs, a statement that the preparation of financial statements uses SAK EMKM as the basis for the preparation used, and accounting policies applied and presented in the financial statements of UMKM Batik Jumput Dahlia. In Batik Jumput Dahlia MSMEs there is no tax burden so the net profit value is still before the tax burden is reduced.
\end{abstract}

Keywords

Correspondence
: Analysis, MSME Financial Report, Batik Jumput.

: andrianto914@yahoo.com

\section{ABSTRAK}

Tujuan penelitian ini untuk mengetahui seperti apa laporan keuangan pada UMKM Batik Jumput Dahlia. Analisis Penyusunan Laporan Keuangan UMKM Batik Jumput Dahlia Berdasarkan SAK-EMKM. Jenis penelitian yang digunakan adalah jenis penelitian kualitatif. Berdasarkan karakteristik masalah yang diangkat oleh peneliti, maka penelitian ini diklarifikasikan sebagai penelitian kualitatif deskriptif. Data yang digunakan dalam penelitian ini yaitu data primer yang diperoleh langsung dari pihak UMKM seperti data hasil wawancara dengan pihak UMKM serta data berupa informasi dari catatan harian kas masuk dan kas keluar. Sedangkan untuk data sekunder diperoleh dari buku, jurnal, internet yang mendukung penelitian ini. Dari hasil analisis data, hasil penelitian menunjukkan bahwa laporan keuangan UMKM Batik Jumput Dahlia menyajikan posisi keuangan tahun 2016 dan 2017 per 31 Desember 2016 menunjukkan total asset Rp 15.128.300,sedangkan per 31 Desember 2017 menunjukkan total asset Rp 11.125.200,- Laba Rugi tahun 2016 nett profit Rp 2.087.100 sedangkan Laba Rugi tahun 2017 nett profit Rp 511.000, Catatan Atas Laporan Keuanga (CALK) menyajikan gambaran umum tentang UMKM Batik Jumput Dahlia, pernyataan bahwa penyusunan laporan keuangan menggunakan SAK EMKM sebagai dasar penyusunan yang digunakan, serta kebijakan akuntansi yang diterapkan dan disajikan dalam laporan 
keuangan UMKM Batik Jumput Dahlia. Pada UMKM Batik Jumput Dahlia belum ada beban pajaknya sehingga nilai laba bersihnya masih sebelum dikurangi beban pajak.

Kata kunci Korespondensi
: Analisis, Laporan Keuangan UMKM, Batik Jumput.

: andrianto914@yahoo.com

\section{PENDAHULUAN / INTRODUCTION}

Indonesia sebagai negara berkembang tidak terlepas dari kegiatan usaha yang di lakukan oleh individu maupun kelompok, Usaha Mikro Kecil dan Menengah (UMKM). Usaha Mikro merupakan kegiatan yang banyak dilakukan masyarakat Indonesia, UMKM sangat berperan penting dalam menciptakan lapangan pekerjaan, sekaligus membantu pemerintah dalam mengurangi angka pengangguran yang ada. Kegiatan UMKM tidak terlepas dari aktivitas akuntansi yang sangat berguna untuk menunjukkan perkembangan atau kondisi keuangan sehingga kelangsungan hidup UMKM dapat terekam dan menjadi bahan untuk mengevaluasi .

Tingginya potensi UMKM dalam perkembangan perekonomian tidak diimbangi dengan kualitas UMKM. Pencatatan dan pengelolaan keuangan yang merupakan salah satu keberhasilan UMKM. Permasalahan yang paling mendasar pada UMKM adalah pencatatan dan penyusunan laporan keuangan yang belum memadai. Hal tersebut karena UMKM terkendala dalam berbagai faktor antara lain kurangnya pengetahuan tentang pencatatan akuntansi. Pelaporan UMKM pada umumnya mencatat jumlah barang diterima dan dikeluarkan, jumlah barang dibeli dan dijual, jumlah piutang dan hutang, tanpa menggunakan standar akuntansi keuangan yang ada, hal tersebut belum mencerminkan informasi keuangan yang sebenarnya.
Informasi akuntansi yang dihasilkan berguna dalam pengambilan keputusan, sehingga dasar pertimbangan antara lain : pembelian bahan baku dan alat-alat produksi, penentuan harga, pengajuan permohonan pembiayaan kepada bank, dan pengembangan sumber daya manusia serta menambahkan aset usaha. Informasi keuangan yang sistematis pada laporan keuangan dapat memudahkan pelaku UMKM mengevaluasi kondisi usaha. Sehingga untuk menjadikan lebih berkualitas.

Pelaku UMKM harus mengerti bagaimana sistem pencatatan akuntansi, apa yang harus dipersiapkan, dan bagaimana menerapkannya sistem pencatatan akuntansi, apa yang harus dipersiapkan dan bagaimana menerapkannya sistem pencatatan akuntansi tersebut sehingga menghasilkan laporan keuangan yang memadai karena informasi keuangan tersebut, merupakan hasil akhir dalam pencatatan akuntansi yang digunakan yang digunakan oleh pihak berkepentingan untuk perkembangan usaha. Menyadari situasi dan kondisi seperti ini, maka diperlukan inovasi dalam penyusunan laporan keuangan yang sesuai dengan standar akuntansi keuangan. UMKM sedikit dipermudah dengan adanya Standar Akuntansi Keuangan Entitas Mikro, Kecil, dan Menengah (SAK EMKM) yang diterbitkan oleh IAI yang dimana SAK EMKM efektif per 1 Januari 2018 Akuntansi Keuangan Entitas Mikro, Kecil, dan Menengah ( SAK EMKM) .

SAK EMKM dapat membantu memudahkan pelaku UMKM dalam 
mengaplikasikan akuntansi pada usaha mereka sehingga dapat dengan mudah menyusun laporan keuangan sesuai dengan standart. Meskipun SAK EMKM terkesan sederhana, namun dapat memberikan informasi yang handal dalam penyajian laporan keuangan. Penyusunan laporan keuangan berdasarkan pada standart akuntansi keuangan merupakan suatu bentuk peningkatan kualitas laporan keuangan yang akan memberikan dampak dalam peningkatan kredibilitas laporan keuangan.

Menurut IAI dalam SAK EMKM (2016:1) Entitas Mikro Kecil dan Menengah (EMKM) merupakan entitas tanpa akuntanbilitas publik yang signifikan yang memenuhi definisi serta kriteria usaha mikro kecil dan menengah sebagaimana diatur dalam peraturan perundang-undangan UU 20 tahun 2018 yang berlaku di Indonesia. Penerapan SAK EMKM selama dua tahun berturut-turut dalam laporan keuangan entitas disusun dengan menggunakan asumsi dasar akrual dan kelangsungan usaha. sebagaimana juga digunakan entitas selain entitas mikro kecil dan menengah serta menggunakan konsep entitas bisnis. Semua pihak sangat akan mengerti pentingnya laporan keuangan dalam usaha.

UMKM di Indonesia belum semuanya mempraktikkan akuntansi dipencatatan keuangannya, masih banyak dari mereka yang menghadapi kendala didalam penyusunan laporan keuangan SAK umum sendiri mungkin lebih rumit untuk dipahami bahkan untuk diterapkan bagi skala usaha kecil menengah, sehingga perlu adanya penerapan SAK EMKM bagi usaha skala kecil menengah dalam membuat laporan keuangan karena lebih mudah di pahami. Adanya SAK EMKM dengan prinsip kesederhanaan diharapkan memberikan kemudahan bagi UMKM dalam menyajikan laporan keuangan untuk membangun kualitas UMKM, dalam kegiatan ekonomi yang sangat penting bagi Indonesia.
Dengan di implementasikannya SAK EMKM terhadap UMKM juga diharapkan membuat berkembangnya UMKM didalam perekonomian Indonesia SAK EMKM member kemudahan untuk UMKM karena ketentuan pelaporan yang mudah di mengerti didalam penerapannya. SAK EMKM pada kenyataannya masih banyak belum diterapkan pada pelaku UKM di Indonesia dalam menyusun laporan keuangannya mengingat bahwa SAK EMKM merupakan Standart Akuntansi Keuangan yang baru dikeluarkan oleh IAI khusus untuk Entitas Mikro Kecil dan Menengah. Adapun objek penelitian yang ingin diteliti adalah UMKM Batik Jumput Dahlia yang bergerak dibidang usaha batik jumput, Sama halnya dengan kondisi pada UMKM, Batik Jumput Dahlia belum mengimplementasikan Standar Akuntansi Keuangan pada laporan keuangannya, karena hanya mencatat kas masuk dan keluar. Sehingga belum sesuai dengan Standar Akuntansi Keuangan Entitas Mikro, Kecil, dan Menengah (SAK EMKM) Dari latar belakang diatas, maka penulis dapat mengambil artikel dengan judul

"Analisis Penyusunan Laporan Keuangan Pada UMKM Batik Jumput Berdasarkan SAK EMKM“"

Tujuan yang ingin dicapai dalam penelitian ini adalah untuk mengetahui bagaimana analisis penyusunan laporan keuangan pada batik jumput berdasarkan SAK EMKM.

\section{KERANGKA TEORI}

\section{Pengertian Laporan Keuangan}

Kesatuan sistem informasi akuntansi yang melaui proses pengklasifikasian, pencatatan, pengikhitisaran akan menghasilkan laporan keuangan. Laporan keuangan yang telah disusun mencerminkan keadaan suatu perusahaan. Para ahli mendefiniskan pengertian laporan keuangan sebagai berikut: 
Pendapat Hans Kartikahadi, dkk. (2016:12) Laporan Keuangan adalah : "Media utama bagi suatu entitas untuk mengkomunikasikan informasi keuangan oleh manajemen kepada para pemangku kepentingan seperti : pemegang saham, kreditur, serikat pekerja, badan pemerintahan, manajemen".

Disisi lain, menurut para ahli laporan keuangan mengandung definisi yaitu : laporan yang menyajikan informasi keuangan dalam suatu periode akuntansi yang dapat digunakan dalam pengambilan keputusan oleh pihak manajemen.

Tujuan laporan keuangan menurut SAK EMKM (2018:3) adalah sebagai berikut:

"Tujuan laporan keuangan adalah untuk menyediakan informasi posisi keuangan dan kinerja suatu entitas yang bermanfaat bagi sejumlah besar pengguna dalam pengambilan keputusan ekonomik oleh siapapun yang tidak dalam posisi dapat meminta laporan keuangan khusus untuk memenuhi kebutuhan informasi tersebut".

Laporan keuangan secara umum terdiri dari :

a. Neraca, yaitu laporan yang menyajikan informasi posisi keuangan yang terdiri dari posisi harta ( aset), kewajiban ( utang ) dan modal ( ekuitas) pada suatu periode akuntansi.

b. Rugi Laba, yaitu laporan yang menyajikan informasi kinerja keuangan perusahaan pada suatu periode akuntansi.

c. Laporan Perubahan modal, yaitu laporan yang menyajikan informasi sebab-sebab berubahnya naik atau turunnya modal keuangan suatu perusahaan pada periode akuntansi.

d. Laporan Arus Kas, yaitu laporan yang menyajikan informasi sebab-sebab berubah naik atau turunnya kas yang terdiri dari kegiatan operasi, pendanaan, dan investasi pada periode akuntansi.

e. Catatan atas laporan keuangan, yaitu laporan yang menyajikan berbagai posisi akun-akun pada laporan keuangan diatas.

\section{Usaha Mikro Kecil dan Menengah ( UMKM )}

Bentuk UMKM dapat berupa perusahaan perseorangan, persekutuan, seperti misalnya firma dan $\mathrm{CV}$, maupun perseroan terbatas. UMKM dapat dikategorikan menjadi tiga terutama berdasar jumlah aset dan omzet sebagaimana tercantum di Undang- Undang Nomor 20 Tahun 2008 tentang UMKM sebagai berikut:

1. Usaha Mikro : Usaha produktif milik perseorangan dan atau badan usaha perseorangan yang memenuhi criteria sebagai berikut :

- Aset $\leq$ Rp50.000.000,00, Memiliki kekayaan bersih kurang dari atau sama dengan Rp50.000.000,00 (lima puluh juta rupiah)

- Omzet $\leq$ Rp300.000.000,00,Memiliki hasil penjualan tahunan kurang dari Rp300.000.000,00 (tiga ratus juta rupiah)

2. Usaha Kecil : Usaha ekonomi produktif yang berdiri sendiri, yang dilakukan oleh orang perorangan atau badan usaha yang bukan merupakan anak perusahaan atau bukan cabang perusahaan yang dimiliki, dikuasai, atau menjadi bagian baik langsung maupun tidak langsung dari usaha menengah atau usaha besar yang memenuhi kriteria sebagai berikut :

- $\operatorname{Rp50.000.000,00<\text {Aset}\leq }$ Rp500.000.000,00, Memiliki kekayaan bersih lebih dari Rp50.000.000,00 (lima puluh juta rupiah) sampai dengan paling banyak Rp500.000.000,00 (lima ratus juta rupiah) tidak termasuk tanah dan bangunan tempat usaha); atau Rp300.000.000,00 < Omzet $\leq$ 2.500.000.000,00, Memiliki hasil penjualan tahunan lebih dari Rp300.000.000,00 (tiga ratus juta rupiah) sampai dengan paling banyak 
Rp2.500.000.000,00 (dua milyar lima ratus juta rupiah).

3. Usaha Menengah: Usaha ekonomi produktif yang berdiri sendiri, yang dilakukan oleh perseorangan atau badan usaha yang bukan merupakan anak perusahaan atau cabang perusahaan yang dimiliki, dikuasai, atau menjadi bagian baik langsung maupun tidak langsung dengan usaha kecil atau usaha besar yang memenuhi kriteria sebagai berikut:

- Rp500.000.000,00 < Aset $\leq$ Rp10.000.000.000,00,Memiliki kekayaan bersih lebih dari Rp500.000.000,00 (lima ratus juta rupiah) sampai dengan paling banyak Rp10.000.000.000,00 (sepuluh milyar rupiah) tidak termasuk tanah dan bangunan tempat usaha; atau

- Rp2.500.000.000,00 < Omzet $\leq$ Rp50.000.000.000,00,Memiliki hasil penjualan tahunan lebih dari Rp2.500.000.000,00 (dua milyar lima ratus juta rupiah) sampai dengan paling banyak Rp50.000.000.000,00 (lima puluh milyar rupiah).

\section{Standar Akuntansi Entitas Mikro Kecil \& Menengah ( SAK EMKM)}

Standart akuntansi keuangan entitas mikro kecil menengah (SAK EMKM) dimaksudkan untuk digunakan oleh entitas mikro kecil dan menengah. Entitas mikro kecil dan menengah adalah entitas tanpa akuntanbilitas publik yang signifikan, sebagaimana didefinisikan dalam standart Akuntansi Keuangan Entitas Tanpa
Akuntabilitas Publik (SAK ETAP) yang memenuhi definisi dan kriteria usaha mikro kecil dan menengah sebagaimana diatur dalam peraturan perundang- undangan yang berlaku di Indonesia, setidak-tidaknya selama 2 tahun berturut-turut.

\section{Penelitian Terdahulu}

Penelitian yang dilakukan oleh Luthfiazahra (2015) dengan judul "Implementasi Standar Akuntansi Keuangan Entitas Tanpa Akuntabilitas Publik (SAK ETAP) Pada UMKM Pengrajin Batik DiKampoeng Batik Laweyan Surakarta". Hasil penelitiannya adalah Berdasarkan Wawancara Terhadap 19 UMKM pengrajin batik, hanya 6 UMKM yang membuat laporan keuangan. 9 responden lainnya tidak membuat laporan keuangan dan tidak menerapkan SAK ETAP, sementara 4 lainnya menggunakan software akuntansi .

Saragih dan Surikayanti (2015) melakukan penelitian dengan judul "Analisis Penerapan Akuntansi dan Kesesuaiannya Dengan SAK ETAP Pada UKM Medan Perjuangan" hasil penelitiannya adalah Pelaku UKM masih kurang memahami akuntansi dan pengelolaan keuangannya, meskipun ada sebagian yang mengetahui. Oleh karena itu Pelaku UKM menggunakan jasa dari karyawan untuk melakukan pencatatan keuangan yang ada diperusahaan atau usaha mereka. Akan tetapi mereka tidak lebih lanjut dalam mengelola pencatatan berdasarkan SAK ETAP karena masih kurangnya pengetahuan dari pelaku UKM atau karyawan yang dipekerjakan untuk membuat pencatatan keuangan dalam membuat laporan keuangan yang berstandar SAK ETAP. 


\section{Kerangka Konseptual}

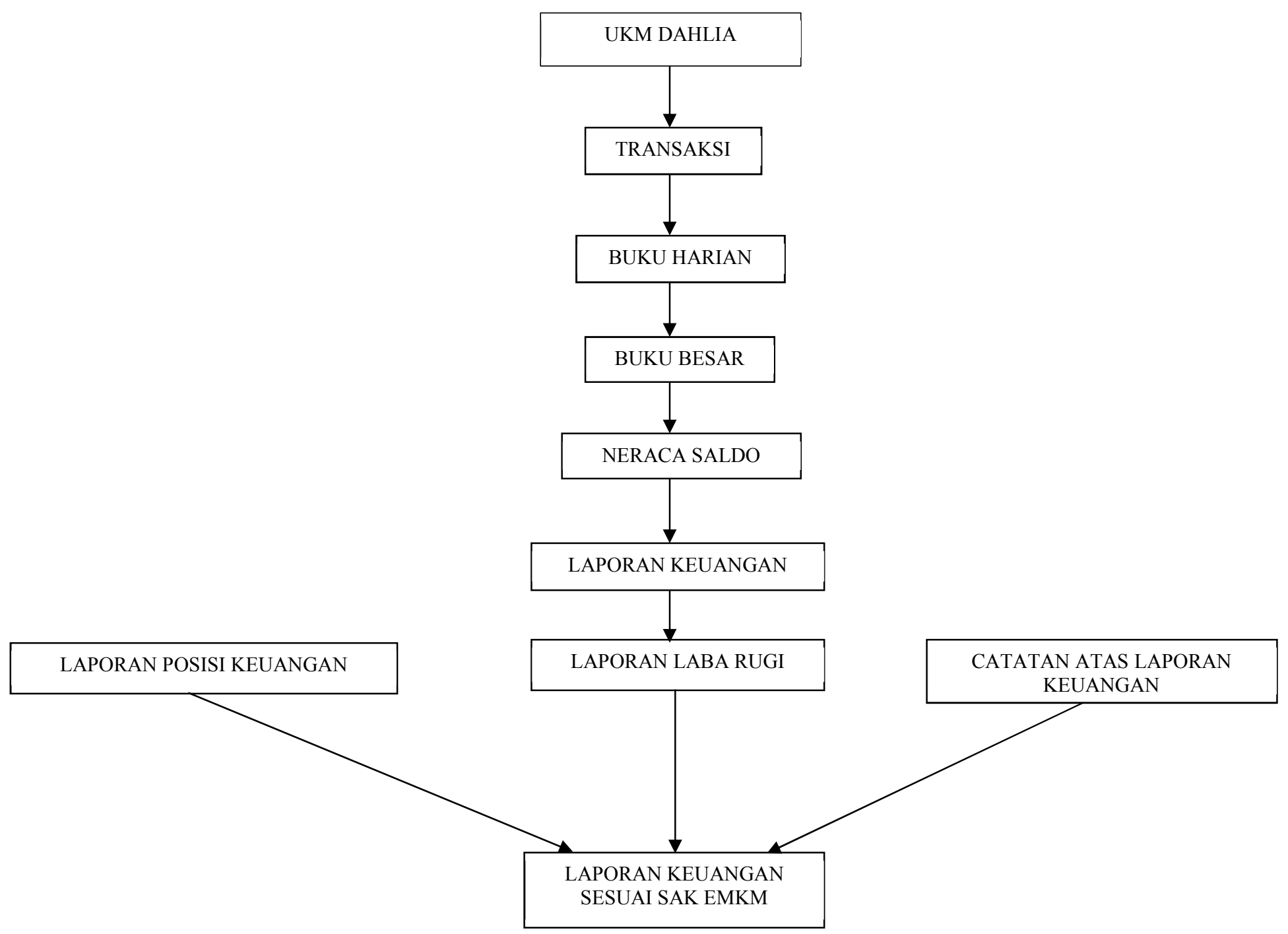

\section{METODE PENELITIAN / METHODS}

\section{Pendekatan Penelitian}

Pendekatan yang digunakan dalam penelitian ini adalah dengan kualitatif deskriptif, yaitu dengan menjelaskan berbagai fenomena yang dialami oleh peneliti dari berbagai sumber kepustakaan. Adapun batasan dalam pendekatan penelitian ini adalah pada laporan kas yang telah disusun oleh pelaku UMKM batik jumput, setelah itu peneliti menjelaskan berbagai teori pada laporan kas tersebut untuk kemudian dilakukan penyusunan laporan keuangan beradasarkan SAK EMKM.

\section{Prosedur Pengumpulan Data}

Prosedur pengumpulan data penelitian ini dikumpulkan dengan menggunakan:

1. Survei Pendahuluan

Langkah prosedur pengumpulan data yang pertama adalah survei pendahuluan pada UMKM Batik Jumput, survei pendahuluan ini dilakukan untuk memperoleh gambaran awal yang jelas tentang UMKM Batik Jumput, dan khususnya tentang data laporan keuangannya agar dapat disusun sesuai dengan SAK EMKM. 
2. Survei Lapangan

Berupa kegiatan observasi. Dokumentasi dilakukan dengan cara mencatat datadata yang berkaitan dengan masalah yang menjadi obyek penelitian.

\section{Pengolahan dan Analisis Data}

Setelah diperoleh data-data tersebut dianalisis dengan langkah-langkah sebagai berikut:

1. Mengumpulkan data-data laporan keuangan terutama laporan kas UMKM Batik Jumput Dahlia dalam bentuk yang sederhana.

2. Data-data berupa struktur terbentuknya UMKM Batik Jumput Dahlia.

3. Melakukan interprestasi hasil penelitian.
HASIL PENELITIAN DAN DISKUSI / RESULTS

\section{Hasil Penelitian}

Dalam penelitian ini, peneliti mengambil data dari UMKM Dahlia di Jl. Ngagel No.11 Surabaya, Balai Kelurahan Ngagel Surabaya. Kecamatan Ngagel, Kelurahan Ngagel, Surabaya. Penelitian ini bertujuan untuk mengetahui seberapa jauh penyusunan laporan keuangan berdasarkan SAK EMKM, sesuai standart peneliti mengambil data selama 2 tahun di tahun 2016 dan 2017 .

Berikut laporan keuangan yang dimiliki UMKM Batik Jumput Dahlia adalah sebagai berikut :

Tabel 4.1

Laporan kas harian UMKM Dahlia Tahun 2016

Jan 2016

\begin{tabular}{|c|l|l|l|l|}
\hline Tanggal & Keterangan & Debet & Kredit & Saldo \\
\hline $1 / 1 / 2016$ & Saldo Desember 2015 & & & Rp 13,041,200 \\
\hline $1 / 17 / 2016$ & $\begin{array}{l}\text { Terima Penjualan } \\
\text { Jilbab }\end{array}$ & $\operatorname{Rp~35,000}$ & & \\
\hline & Jumlah & Rp 13,076,200 & & Rp 13,076,200 \\
\hline
\end{tabular}

Feb 2016

\begin{tabular}{|c|c|c|c|c|c|}
\hline Tanggal & Keterangan & Debet & \multicolumn{2}{|c|}{ Kredit } & Saldo \\
\hline $1 / 1 / 2016$ & Saldo Januari 2016 & & & & Rp $13,076,200$ \\
\hline \multirow[t]{2}{*}{$2 / 19 / 2016$} & $\begin{array}{l}\text { Pembelian } 4 \text { Wenter } \\
\text { dan garam }\end{array}$ & & $\mathrm{Rp}$ & 20,000 & \\
\hline & Jumlah & Rp 13,076,200 & $\mathrm{Rp}$ & 20,000 & Rp $13,056,200$ \\
\hline
\end{tabular}

Mar 2016

\begin{tabular}{|c|l|l|l|l|}
\hline Tanggal & Keterangan & Debet & Kredit & Saldo \\
\hline 3/1/2016 & Saldo Februari 2016 & & & Rp 13,056,200 \\
\hline & Jumlah & Rp 13,056,200 & & Rp 13,056,200 \\
\hline
\end{tabular}


Balance Vol. XVI No. 1 | Januari 2019

Apr 2016

\begin{tabular}{|c|c|c|c|c|c|c|}
\hline Tanggal & Keterangan & \multicolumn{2}{|c|}{ Debet } & \multicolumn{2}{|c|}{ Kredit } & Saldo \\
\hline $4 / 1 / 2016$ & Saldo Maret 2016 & & & & & Rp 13,056,200 \\
\hline $4 / 20 / 2016$ & $\begin{array}{l}\text { Pembelian Wenter } \\
\text { @ Rp } 25000+\mathrm{LPG} \\
\text { a.Rp } 18000\end{array}$ & & & $\mathrm{Rp}$ & 43,000 & \\
\hline $4 / 23 / 2016$ & Penjualan Batik & $\mathrm{Rp}$ & 400,000 & & & \\
\hline $4 / 23 / 2016$ & $\begin{array}{l}\text { Penjualan Batik } 1 \\
\text { potong batik jumput }\end{array}$ & $\mathrm{Rp}$ & 160,000 & & & \\
\hline $4 / 23 / 2016$ & $\begin{array}{l}\text { Pembelian Rafia }+ \\
\text { Kacang Hijau }\end{array}$ & & & $\mathrm{Rp}$ & 60,000 & \\
\hline $4 / 23 / 2016$ & Santunan & & & $\mathrm{Rp}$ & 200,000 & \\
\hline & Jumlah & $\mathrm{Rp}$ & 616,200 & $\mathrm{Rp}$ & 303,000 & Rp $13,313,200$ \\
\hline
\end{tabular}

Mei 2016

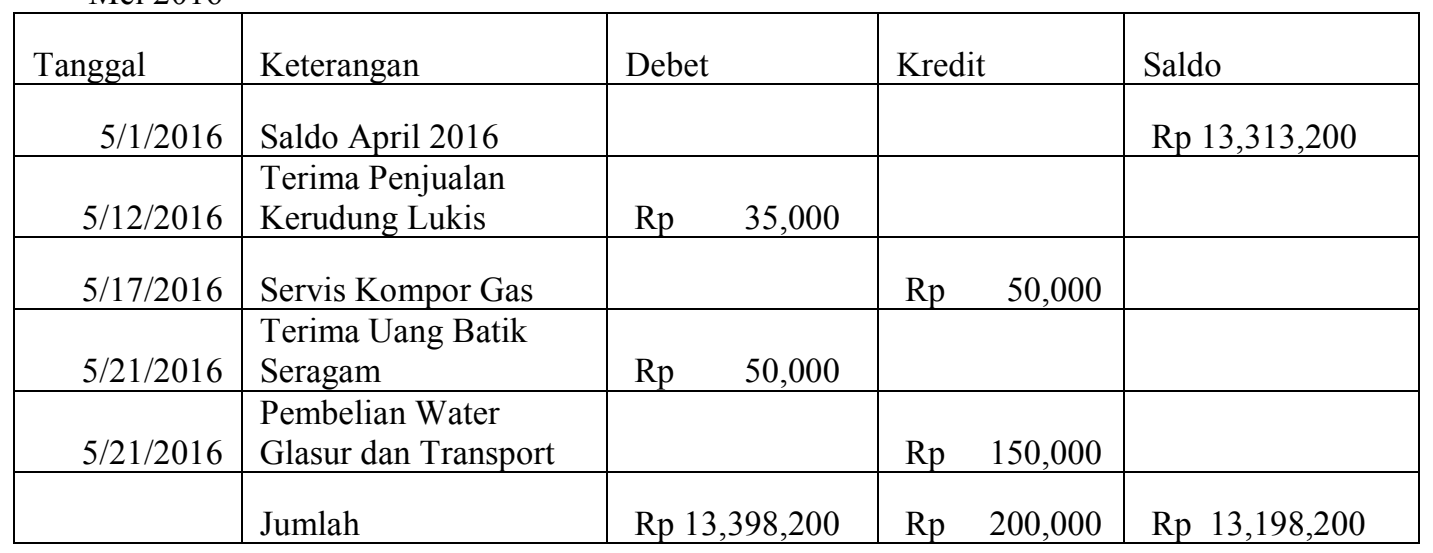

Jun 2016

\begin{tabular}{|c|l|l|l|l|}
\hline Tanggal & Keterangan & Debet & Kredit & Saldo \\
\hline $6 / 1 / 2016$ & Saldo Mei 2016 & & & Rp 13,198,200 \\
\hline $6 / 8 / 2016$ & Terima 2 Lembar Kain & $\mathrm{Rp} \mathrm{100,000}$ & & \\
\hline $6 / 8 / 2016$ & $\begin{array}{l}\text { Honor untuk membuat } \\
\text { Batik }\end{array}$ & & & \\
& Bu A & & $\mathrm{Rp} \mathrm{600,000}$ & \\
\hline & Bu B & & $\mathrm{Rp} \mathrm{400,000}$ & \\
\hline & Bu C & & $\mathrm{Rp} \mathrm{150,000}$ & \\
\hline & Bu D & & $\mathrm{Rp} \mathrm{200,000}$ & \\
\hline & $\begin{array}{l}\text { Terima Pembelian 1 } \\
\text { Lembar Batik 2 Meter }\end{array}$ & $\mathrm{Rp} 110,000$ & & \\
\hline $6 / 13 / 2016$ & & & \\
\hline
\end{tabular}


Balance Vol. XVI No. 1 | Januari 2019

\begin{tabular}{|l|l|l|l|l|}
\hline $6 / 14 / 2018$ & $\begin{array}{l}\text { Pembeian LPG 3x@Rp } \\
18000\end{array}$ & & $\mathrm{Rp} \mathrm{54,000}$ & \\
\hline $6 / 14 / 2018$ & Pembelian & & & \\
\hline & Wenter & & $\mathrm{Rp} \mathrm{97,500}$ & \\
\hline & Garam & & $\mathrm{Rp} \mathrm{10,000}$ & \\
\hline & Jumlah & $\mathrm{Rp} \mathrm{13,408,200}$ & $\mathrm{Rp} \mathrm{1,511,500}$ & $\mathrm{Rp} \mathrm{11,896,700}$ \\
\hline
\end{tabular}

Jul 2016

\begin{tabular}{|c|l|l|l|l|}
\hline Tanggal & Keterangan & Debet & Kredit & Saldo \\
\hline $7 / 1 / 2016$ & Saldo Juni & & & Rp 11,896,700 \\
\hline $7 / 25 / 2016$ & Teria Penjualan Batik & Rp 110,000 & & \\
\hline & Jumlah & Rp 12,006,700 & & Rp 12,006,700 \\
\hline
\end{tabular}

Agt 2016

\begin{tabular}{|c|c|c|c|c|}
\hline Tanggal & Keterangan & Debet & Kredit & Saldo \\
\hline $8 / 1 / 2010$ & & & & \\
\hline $8 / 1 / 2016$ & $\begin{array}{l}\text { Terima Penjualan } \\
\text { Batik } 2 \text { Meter }\end{array}$ & $\mathrm{Rp} \quad 100,000$ & & \\
\hline $8 / 1 / 2016$ & $\begin{array}{l}\text { Pembelian } 12 \text { biji } \\
\text { wantex }\end{array}$ & & 30,000 & \\
\hline $8 / 4 / 2016$ & $\begin{array}{l}\text { Pembelian } 10 \text { lembar } \\
\text { kain jilbab }\end{array}$ & & $\mathrm{Rp} \quad 200,000$ & \\
\hline $8 / 10 / 2016$ & $\begin{array}{l}\text { Bayar Transport } \\
\text { Pameran Grand City }\end{array}$ & & $\mathrm{Rp} \quad 150,000$ & \\
\hline \multirow[t]{5}{*}{$8 / 15 / 2016$} & Pembelian 2 pc Kain & & Rp $1,100,000$ & \\
\hline & Transport & & 25,000 & \\
\hline & Wantex & & 10,000 & \\
\hline & Wantex & & 15,000 & \\
\hline & LPG & & 18,000 & \\
\hline $8 / 21 / 2016$ & $\begin{array}{l}\text { Pembelian Kacang } \\
\text { Hijau, benang }\end{array}$ & & 100,000 & \\
\hline $8 / 21 / 2016$ & Pembelian Payet & & 20,000 & \\
\hline $8 / 24 / 2016$ & $\begin{array}{l}\text { Uber PP Pasang } \\
\text { pameran di AR. Hakim }\end{array}$ & & 42,000 & \\
\hline $8 / 25 / 2016$ & $\begin{array}{l}\text { Uber PP Pasang } \\
\text { pameran di AR. Hakim }\end{array}$ & & 20,000 & \\
\hline \multirow[t]{2}{*}{$8 / 25 / 2016$} & Taksi Pulang Pameran & & 55,000 & \\
\hline & Jumlah & Rp $12,106,700$ & 1785000 & $\operatorname{Rp} 10,321,700$ \\
\hline
\end{tabular}


Balance Vol. XVI No. 1 | Januari 2019

Sep 2016

\begin{tabular}{|c|c|c|c|c|c|c|}
\hline Tanggal & Keterangan & \multicolumn{2}{|c|}{ Debet } & \multicolumn{2}{|c|}{ Kredit } & Saldo \\
\hline $8 / 1 / 2016$ & Saldo Agustus 2016 & & & & & Rp 10,321,700 \\
\hline $9 / 1 / 2016$ & $\begin{array}{l}\text { Biaya Servis Kompor } \\
\text { Gas }\end{array}$ & & & $\mathrm{Rp}$ & 40,000 & \\
\hline 9/7/2016 & Terima Batik 2 Meter & $\mathrm{Rp}$ & 100,000 & & & \\
\hline $9 / 7 / 2016$ & $\begin{array}{l}\text { Terima Batik } 1 \text { set } \\
\text { rukuh }\end{array}$ & & 150,000 & & & \\
\hline \multirow[t]{2}{*}{$9 / 14 / 2016$} & Pembelian Wenter & & & $\mathrm{Rp}$ & 92,000 & \\
\hline & LPG 2 & & & $\mathrm{Rp}$ & 36,000 & \\
\hline $9 / 16 / 2016$ & $\begin{array}{l}\text { Pembelian } 12 \text { biji } \\
\text { wenter }\end{array}$ & & & $\mathrm{Rp}$ & 30,000 & \\
\hline \multirow[t]{6}{*}{$9 / 17 / 2016$} & $\begin{array}{l}\text { Terima Penjualan } \\
\text { Batik Pameran di } \\
\text { Gramedia Expo }\end{array}$ & & & & & \\
\hline & $\begin{array}{l}3 \text { potong pagi sore } \\
\text { (a) } \operatorname{Rp} 5 \mathbf{5 5 , 0 0 0}\end{array}$ & & & & & \\
\hline & $\begin{array}{l}2 \text { potong kerudung } \\
\text { lukis @Rp } 70,000\end{array}$ & & & & & \\
\hline & $\begin{array}{l}1 \text { potong mukena } \\
\text { (a) Rp150,000 }\end{array}$ & & & & & \\
\hline & $\begin{array}{l}1 \text { potong } 2 \text { Meter } \\
@ \text { Rp } 120,000\end{array}$ & & & & & \\
\hline & uang yang diterima & $\mathrm{Rp}$ & 750,000 & & & \\
\hline $9 / 17 / 2016$ & Bayar Transport & & & $\mathrm{Rp}$ & 100,000 & \\
\hline \multirow[t]{2}{*}{$9 / 17 / 2016$} & $\begin{array}{l}\text { Ongkos Jahit } 6 \text { Potong } \\
\text { Mukena }\end{array}$ & & & $\mathrm{Rp}$ & 150,000 & \\
\hline & Jumlah & & $1,321,700$ & $\mathrm{Rp}$ & 448,000 & Rp $10,873,700$ \\
\hline
\end{tabular}

Okt 2016

\begin{tabular}{|c|c|c|c|c|}
\hline Tanggal & Keterangan & Debet & Kredit & Saldo \\
\hline $10 / 1 / 2016$ & Saldo September 2016 & & & $\operatorname{Rp} 10,873,700$ \\
\hline \multirow[t]{3}{*}{$10 / 1 / 2016$} & $\begin{array}{l}\text { Pembelian Wantex } \\
@ \text { Rp 60,000 }\end{array}$ & & & \\
\hline & $1 \mathrm{LPG} @ \mathrm{Rp} 18,000$ & & & \\
\hline & Total yang dikeluarkan & & $\mathrm{Rp} \quad 78,000$ & \\
\hline $10 / 3 / 2016$ & $\begin{array}{l}\text { Pembelian } 10 \text { wantex } \\
@ \text { Rp } 25,000\end{array}$ & & & \\
\hline & LPG $1 @$ Rp 18,000 & & & \\
\hline & $\begin{array}{l}\text { Regulator @Rp } \\
115,000\end{array}$ & & & \\
\hline
\end{tabular}


Balance Vol. XVI No. 1 | Januari 2019

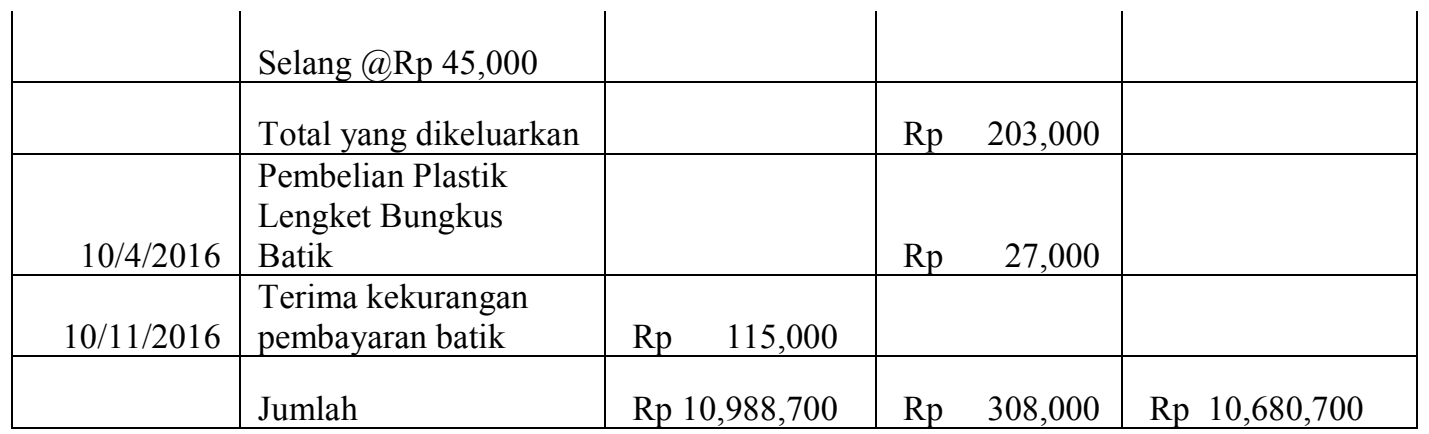

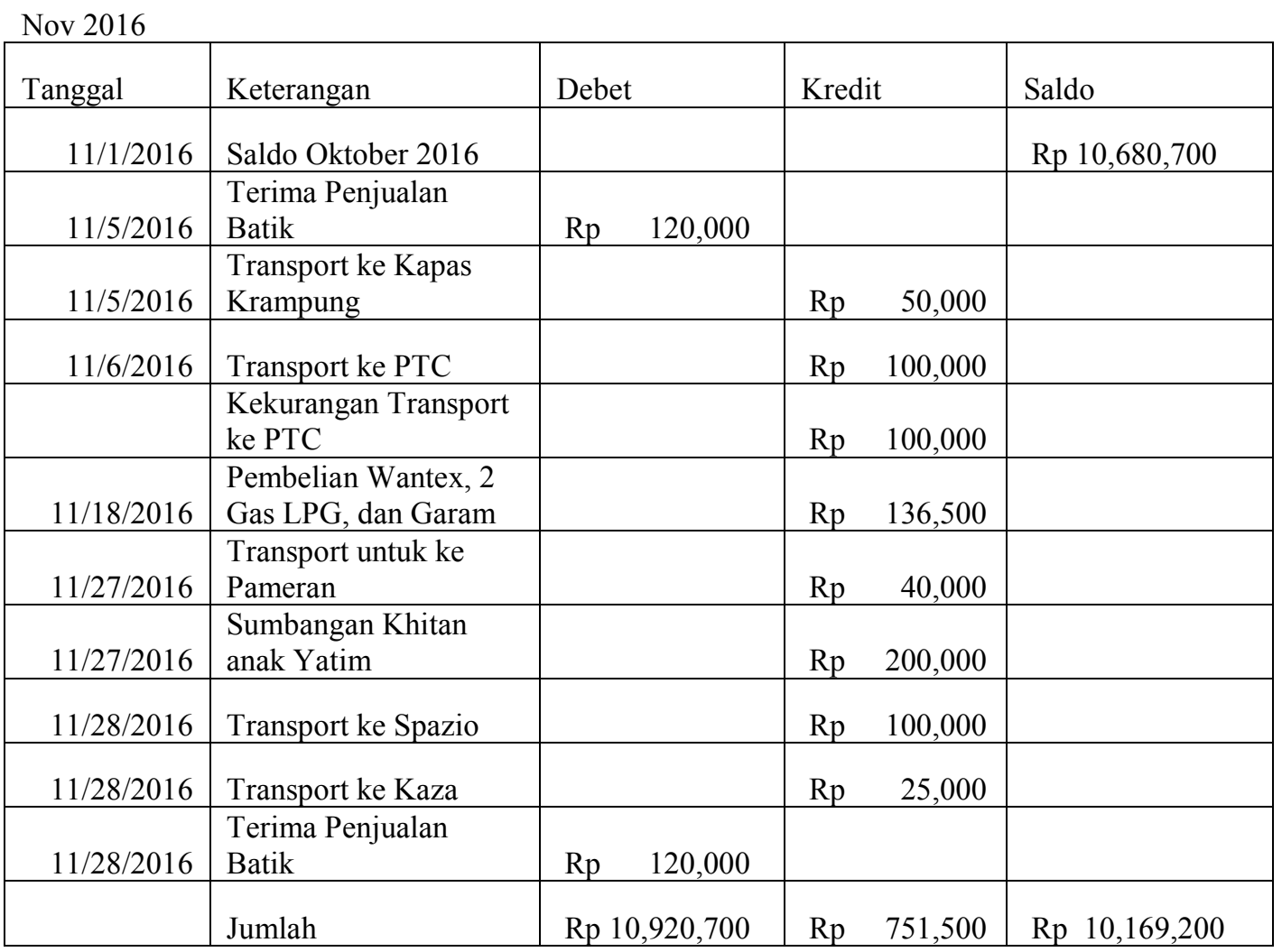

Des 2016

\begin{tabular}{|c|l|l|l|l|}
\hline Tanggal & Keterangan & Debet & Kredit & Saldo \\
\hline $11 / 1 / 2016$ & Saldo November 2016 & & & Rp 10,169,200 \\
\hline & Transport di Taman & & Rp 120,000 & \\
\hline Surya & & & \\
& Terima Penjualan & & & \\
& Batik di Pameran Balai & & & \\
& Kota & & & \\
\hline & 1 potong pagi sore & & & \\
& $@$ Rp 175,000 & & & \\
\hline & 1 potong pagi sore & & & \\
& @Rp 170,000 & & & \\
\hline
\end{tabular}


Balance Vol. XVI No. 1| Januari 2019

\begin{tabular}{|c|c|c|c|c|c|c|}
\hline & $\begin{array}{l}\text { 1 Mukena@Rp } \\
150,000\end{array}$ & & & & & \\
\hline & Total Penjualan & $\mathrm{Rp}$ & 495,000 & & & \\
\hline $12 / 15 / 2016$ & $\begin{array}{l}\text { Terima Penjualan } \\
\text { Kerudung }\end{array}$ & & 70,000 & & & \\
\hline & Jumlah & $\mathrm{Rp}$ & $, 734,200$ & $\mathrm{Rp}$ & 120,000 & $\operatorname{Rp} 10,614,200$ \\
\hline
\end{tabular}

(Sumber : Laporan Keuangan UMKM Batik Jumput Dahlia )

Tabel 4.2

Laporan Keuangan Catatan Harian UMKM Dahlia Tahun 2017

Jan 2017

\begin{tabular}{|c|l|l|l|l|}
\hline Tanggal & Keterangan & Debet & Kredit & Saldo \\
\hline $1 / 1 / 2017$ & Saldo Desember 2016 & & & Rp 10.614.200 \\
\hline $1 / 17 / 2017$ & Terima Penjualan Batik 2 potong & Rp 240.000 & & \\
\hline & Jumlah & Rp 834.200 & & Rp 10.834.200 \\
\hline
\end{tabular}

Feb 2017

\begin{tabular}{|c|l|l|l|l|}
\hline Tanggal & Keterangan & Debet & Kredit & Saldo \\
\hline $1 / 2 / 2017$ & Saldo Januari 2017 & & & $\mathrm{Rp} \mathrm{10.834.200}$ \\
\hline $12 / 2 / 2017$ & Penjualan & Rp 170.000 & & \\
\hline $16 / 02 / 2017$ & Pembelian Wenter & & $\mathrm{Rp} \mathrm{45.000}$ & \\
\hline & Jumlah & $\mathrm{Rp}$ & & \\
& 11.004 .200 & $\mathrm{Rp} \mathrm{45.000}$ & $\mathrm{Rp} \mathrm{10.959.200}$ \\
\hline
\end{tabular}

Mar 2017

\begin{tabular}{|c|l|l|l|l|}
\hline Tanggal & Keterangan & Debet & Kredit & Saldo \\
\hline $3 / 1 / 2017$ & Saldo Februari 2017 & & & Rp 10.959.200 \\
\hline $6 / 3 / 2017$ & $\begin{array}{l}\text { Pembelian 4 pcs kain dan } \\
\text { transport }\end{array}$ & & $\mathrm{Rp} \mathrm{2.225.000}$ & \\
\hline $7 / 3 / 2017$ & Pembelian 20 wenter dan 1pg & & $\mathrm{Rp} \mathrm{68.000}$ & \\
\hline $31 / 03 / 2017$ & Transport & & $\mathrm{Rp} \mathrm{100.000}$ & \\
\hline & Jumlah & $\begin{array}{l}\mathrm{Rp} \\
10.595 .200\end{array}$ & $\mathrm{Rp} \mathrm{2.393.000}$ & $\mathrm{Rp} \mathrm{8.566.200}$ \\
\hline
\end{tabular}

Apr 2017

\begin{tabular}{|l|l|l|l|l|}
\hline Tanggal & Keterangan & Debet & Kredit & Saldo \\
\hline \multicolumn{1}{|c|}{$4 / 1 / 2017$} & Saldo Maret 2017 & & & Rp 8.566.200 \\
\hline $16 / 04 / 2017$ & Pembelian 1 pack plastik & & $\operatorname{Rp~21.000~}$ & \\
\hline $16 / 04 / 2017$ & Pembelian dedelan luar & & $\operatorname{Rp~25.000}$ & \\
\hline $16 / 04 / 2017$ & Pembelian Rafia + Kacang Hijau & & $\operatorname{Rp~50.000~}$ & \\
\hline $19 / 04 / 2017$ & Terima Penjualan 1 potong kain & Rp 120.000 & & \\
\hline $22 / 04 / 2017$ & $\begin{array}{l}\text { Pembelian enter, garam alat dedel } \\
\text { dan lpg }\end{array}$ & & $\operatorname{Rp~177.500~}$ & \\
\hline $30 / 04 / 2017$ & Pembelian Lpg & Rp 18.000 & \\
\hline \hline
\end{tabular}


Balance Vol. XVI No. 1| Januari 2019

Jumlah

\begin{tabular}{l|l|l}
$\mathrm{Rp}$ 8.686.200 & $\mathrm{Rp} 291.500$ & $\mathrm{Rp} 8.394 .700$
\end{tabular}

Mei 2017

\begin{tabular}{|c|l|l|l|l|}
\hline Tanggal & Keterangan & Debet & Kredit & Saldo \\
\hline $5 / 1 / 2017$ & Saldo April 2017 & & & Rp 8.394.700 \\
\hline $18 / 05 / 2017$ & pembelian 10 wenter dan lpg & & Rp 43.000 & \\
\hline & Jumlah & Rp 8.394.700 & Rp 43.000 & Rp 8.351.700 \\
\hline
\end{tabular}

Jun 2017

\begin{tabular}{|c|l|l|l|l|}
\hline Tanggal & Keterangan & Debet & Kredit & Saldo \\
\hline $6 / 1 / 2017$ & Saldo Mei 2017 & & & Rp 8.351.700 \\
\hline $6 / 1 / 2017$ & Pembelian 22 wantex & & Rp 55.000 & \\
\hline $6 / 1 / 2017$ & Pembelian 2 Lpg & & Rp 36.000 & \\
\hline $6 / 2 / 2017$ & Buka Rek Tab Mandiri & & & \\
\hline $6 / 2 / 2017$ & Honor untuk membuat Batik 100.000 & \\
\hline & Bu A & & Rp 450.000 & \\
\hline & Bu B & & $\operatorname{Rp~450.000~}$ & \\
\hline & Bu C & & $\operatorname{Rp~450.000~}$ & \\
\hline & Bu D & & $\operatorname{Rp~450.000~}$ & \\
\hline & Jumlah & $\operatorname{Rp~} 8.351 .700$ & $\operatorname{Rp~1.988.000~}$ & Rp 6.543.700 \\
\hline
\end{tabular}

Jul 2017

\begin{tabular}{|c|c|c|c|c|}
\hline Tanggal & Keterangan & Debet & Kredit & Saldo \\
\hline $7 / 1 / 2017$ & Saldo Juni & & & Rp 6.543.700 \\
\hline $7 / 1 / 2017$ & Pembelian wantex & & Rp 85.000 & \\
\hline $7 / 1 / 2017$ & Pembelian 2 lpg & & Rp 36.000 & \\
\hline $7 / 1 / 2017$ & Pembelian garam & & Rp 15.000 & \\
\hline $7 / 4 / 2017$ & Pembelian wantex & & Rp 77.500 & \\
\hline $7 / 10 / 2017$ & Pembelian lpg & & Rp 18.000 & \\
\hline $7 / 16 / 2017$ & Transport & & Rp 50.000 & \\
\hline $7 / 29 / 2017$ & Penjualan di lapangan flores & Rp 840.000 & & \\
\hline \multirow[t]{2}{*}{$7 / 29 / 2017$} & Transport & & Rp 100.000 & \\
\hline & Jumlah & Rp 7.373.700 & Rp 381.500 & Rp 6.992.200 \\
\hline
\end{tabular}

Agt 2017

\begin{tabular}{|c|l|l|l|l|}
\hline Tanggal & Keterangan & Debet & Kredit & Saldo \\
\hline $8 / 1 / 2017$ & Saldo Juli 2017 & & & Rp 6.992.200 \\
\hline $8 / 30 / 2017$ & $\begin{array}{l}\text { Terima Penjualan Batik untuk } \\
\text { seragam }\end{array}$ & Rp 1.560.000 & & \\
\hline $8 / 30 / 2017$ & Penjualan Batik & Rp 175.000 & & \\
\hline
\end{tabular}


Balance Vol. XVI No. 1| Januari 2019

Jumlah

Rp 8.467.200

Rp 8.467.200

Sep 2017

\begin{tabular}{|c|l|l|l|l|}
\hline Tanggal & Keterangan & Debet & Kredit & Saldo \\
\hline $9 / 1 / 2017$ & Saldo Agustus 2017 & & & Rp 8.467.200 \\
\hline $9 / 15 / 2017$ & $\begin{array}{l}\text { Terima penjualan batik untuk } \\
\text { seragam }\end{array}$ & Rp 420.000 & & \\
\hline $9 / 20 / 2017$ & Pembelian antex, garam dan lpg & & Rp 168.500 & \\
\hline & Jumlah & Rp 9.067.200 & Rp 168.500 & $\operatorname{Rp~8.898.700~}$ \\
\hline
\end{tabular}

Okto 2017

\begin{tabular}{|c|l|l|l|l|}
\hline Tanggal & Keterangan & Debet & Kredit & Saldo \\
\hline $10 / 1 / 2017$ & Saldo September 2017 & & & Rp 8.898.700 \\
\hline $10 / 20 / 2017$ & Terima penjualan 7 potong kain & Rp 260.000 & & \\
\hline $10 / 20 / 2017$ & Terima penjualan kain pagi sore & Rp 175.000 & & \\
\hline $10 / 23 / 2017$ & $\begin{array}{l}\text { Pembelian wantex, lpg dam } \\
\text { transport }\end{array}$ & & Rp 163.000 & \\
\hline & Jumlah & Rp 9.333.700 & Rp 163.000 & $\operatorname{Rp~9.170.700~}$ \\
\hline
\end{tabular}

Nov 2017

\begin{tabular}{|c|l|l|l|l|}
\hline Tanggal & Keterangan & Debet & Kredit & Saldo \\
\hline $11 / 1 / 2017$ & Saldo Oktober 2017 & & & Rp 9.170.700 \\
\hline $11 / 9 / 2017$ & Terima Penjualan Batik & Rp 360.000 & & \\
\hline $11 / 15 / 2017$ & Transport & & Rp 150.000 & \\
\hline $11 / 15 / 2017$ & Transport & & Rp 150.000 & \\
\hline $11 / 15 / 2017$ & Pembelian Paner & & Rp 150.000 & \\
\hline $11 / 15 / 2017$ & Terima Penjualan Batik & Rp 360.000 & & \\
\hline $11 / 16 / 2017$ & Terima Penjualan Batik & $R p ~ 120.000$ & & \\
\hline & Jumlah & $R p ~ 9.915 .700$ & $R p ~ 450.000$ & Rp 9.465.700 \\
\hline
\end{tabular}

Des 2017

\begin{tabular}{|r|l|l|l|l|}
\hline Tanggal & Keterangan & Debet & Kredit & Saldo \\
\hline $12 / 1 / 2017$ & Saldo November 2017 & & & Rp 9.465.700 \\
\hline $12 / 7 / 2017$ & Transport & & Rp 150.000 & \\
\hline $12 / 4 / 2017$ & Terima Penjualan Batik & Rp 175.000 & & \\
\hline $12 / 9 / 2017$ & Pembelian wantex dan lpg & & Rp 125.500 & \\
\hline $12 / 17 / 2017$ & Terima penjualan kain batik & Rp 1.680 .000 & & \\
\hline $12 / 23 / 2017$ & Terima penjualan batik & Rp 110.000 & & \\
\hline $12 / 23 / 2017$ & Terima penjualan batik & Rp 100.000 & & \\
\hline $12 / 23 / 2017$ & Terima penjualan batik & $R p ~ 175.000$ & & \\
\hline
\end{tabular}


Balance Vol. XVI No. 1| Januari 2019

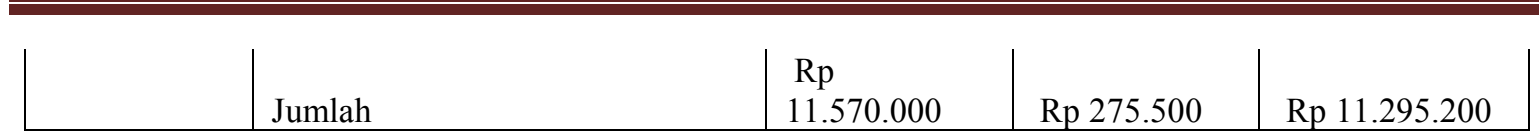

(Sumber : Laporan Kas Harian UMKM Batik Jumput Dahlia )

Laporan Keuangan yang di susun UMKM Batik Jumput Dahlia hanya memberikan informasi arus kas seperti contoh di atas sehingga belum bisa mencerminkan laporan keuangan yang sesungguhnya dengan SAK yang berlaku.

\section{Diskusi}

\section{Jurnal Umum}

Langkah awal dalam penyusunan laporan keuangan adalah membuat jurnal. Penjurnalan untuk mencatat transaksi suatu perusahaan yang dilakukan secara sistematis dengan menggunakan akun yang di debet dan di kredit. Seluruh transaksi yang terjadi dalam suatu perusahaan harus di catat dalam jurnal kemudian dibukukan kedalam buku besar. Proses penjurnalan adalah untuk menulis transaksi keuangan terjadi pada UMKM Batik Jumput Dahlia.

Data yang dibutuhkan untuk membuat jurnal umum adalah transaksi yang dilakukan UMKM Batik Jumput Dahlia dalam 2 tahun dengan mengggunakan daftar perkiraan sebagai berikut:

\section{Daftar Perkiraan}

\begin{tabular}{|l|l|}
\hline No Perkiraan & Nama Perkiraan \\
\hline 11 & Kas \\
\hline 31 & Modal \\
\hline 41 & Penjualan \\
\hline 50 & Pembelian \\
\hline 51 & Beban lain-lain \\
\hline 52 & Beban transport \\
\hline 53 & beban Servis \\
\hline 54 & Beban jahit \\
\hline 55 & Beban Gaji \\
\hline
\end{tabular}

Berikut jurnal umum UMKM Batik Jumput Dahlia :

\section{UMKM Batik Jumput Dahlia}

Daftar Perkiraan

Desember 2016

\begin{tabular}{|l|r|r|l|r|l|l|}
\hline No & \multicolumn{1}{|l|}{ Tanggal } & \multicolumn{1}{l|}{ Nama Rekening } & \multicolumn{1}{l|}{ Ref } & Debit & Kul : \\
\hline 1 & Des-16 & 1 & Kas & 11 & Rp 13,041,200 & \\
\hline & & & Modal & 31 & & Rp 13,041,200 \\
\hline & & 2 & Kas & 11 & Rp 8,160,000 & \\
\hline & & & Penjualan & 41 & & Rp 8,160,000 \\
\hline
\end{tabular}


Balance Vol. XVI No. 1| Januari 2019

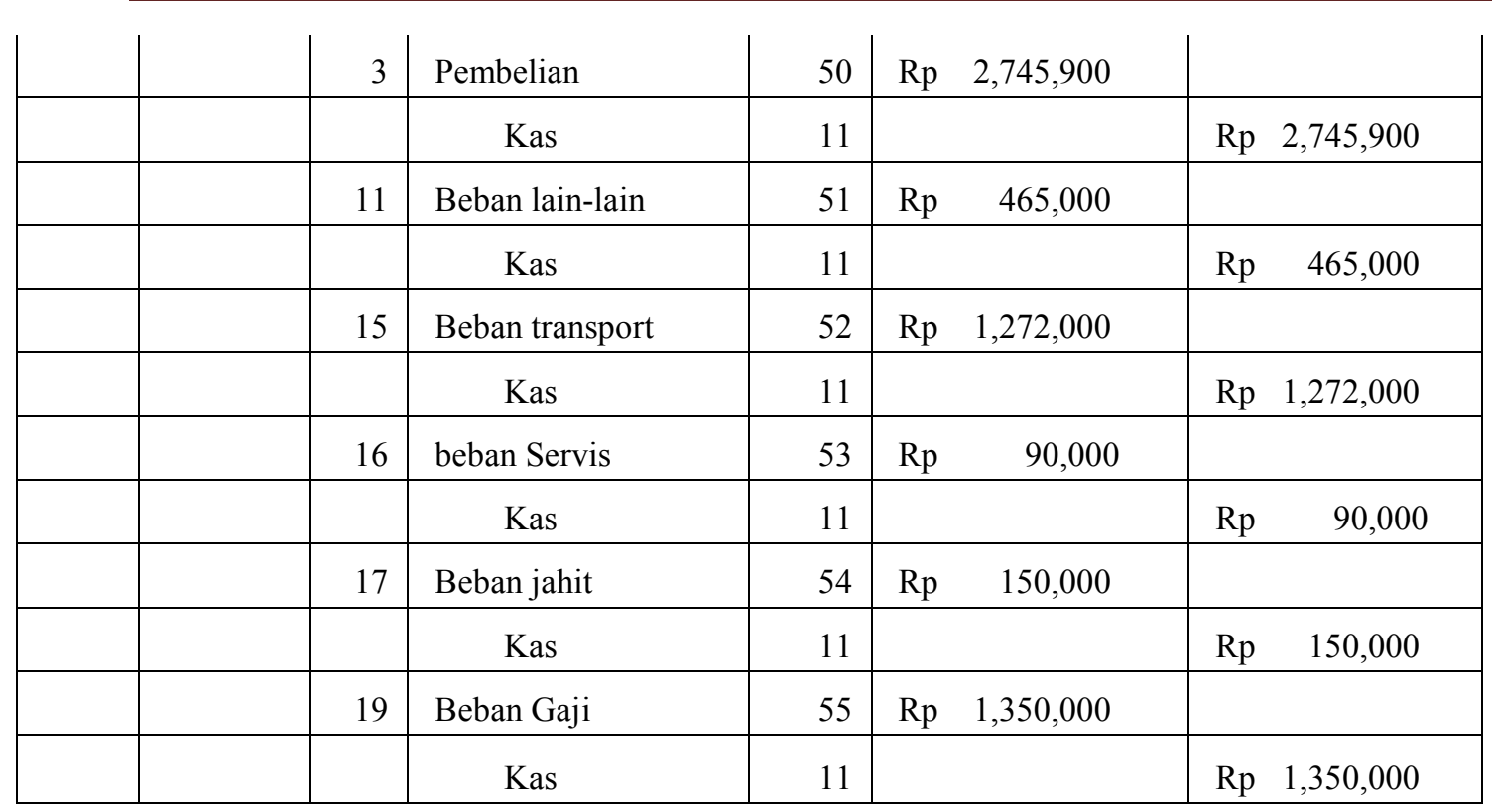

(Sumber : Diolah oleh peneliti 2018)

Tabel 4.5

\section{UMKM Batik Jumput Dahlia}

Daftar Perkiraan

Desember 17

Hal :

JU-1

\begin{tabular}{|c|c|c|c|c|c|c|c|c|}
\hline No & \multicolumn{2}{|l|}{ Tanggal } & Nama Rekening & Ref & Deb & & \multicolumn{2}{|c|}{ Kredit } \\
\hline 1 & Des-17 & 1 & Kas & 11 & $\mathrm{Rp}$ & $10,614,200$ & & \\
\hline & & & Modal & 31 & & & $\mathrm{Rp}$ & $10,614,200$ \\
\hline & & 2 & Kas & 11 & $\mathrm{Rp}$ & $6,710,000$ & & \\
\hline & & & Penjualan & 41 & & & $\mathrm{Rp}$ & $6,710,000$ \\
\hline & & 3 & Beban Pembelian & 50 & $\mathrm{Rp}$ & $3,574,000$ & & \\
\hline & & & Kas & 11 & & & $\mathrm{Rp}$ & $3,574,000$ \\
\hline & & 11 & Beban lain-lain & 51 & $\mathrm{Rp}$ & 200,000 & & \\
\hline & & & Kas & 11 & & & $\mathrm{Rp}$ & 200,000 \\
\hline & & 15 & Beban transport & 52 & $\mathrm{Rp}$ & 625,000 & & \\
\hline & & & Kas & 11 & & & $\mathrm{Rp}$ & 625,000 \\
\hline & & 19 & Beban Gaji & 55 & $\mathrm{Rp}$ & $1,800,000$ & & \\
\hline & & & Kas & 11 & & & $\mathrm{Rp}$ & $1,800,000$ \\
\hline
\end{tabular}

(Sumber : Diolah oleh peneliti 2018)

Neraca Saldo

Batik Jumput Dahlia

Neraca Saldo

Untuk Periode yang berakhir 31 Desember 2016

\begin{tabular}{|l|l|l|l|}
\hline Nama perkiraan & Ref & Debit & Kredit \\
\hline
\end{tabular}


Balance Vol. XVI No. 1 | Januari 2019

\begin{tabular}{|c|c|c|c|c|c|}
\hline Kas & 11 & $\mathrm{Rp}$ & $15,128,300$ & $\mathrm{Rp}$ & - \\
\hline Modal & 31 & $\mathrm{Rp}$ & - & $\mathrm{Rp}$ & $13,041,200$ \\
\hline Penjualan & 41 & $\mathrm{Rp}$ & - & $\mathrm{Rp}$ & $8,160,000$ \\
\hline Pembelian & 50 & $\mathrm{Rp}$ & $2,745,900$ & $\mathrm{Rp}$ & - \\
\hline Beban lain-lain & 51 & $\mathrm{Rp}$ & 465,000 & $\mathrm{Rp}$ & - \\
\hline Beban transport & 52 & $\mathrm{Rp}$ & $1,272,000$ & $\mathrm{Rp}$ & - \\
\hline beban Servis & 53 & $\mathrm{Rp}$ & 90,000 & $\mathrm{Rp}$ & - \\
\hline Beban jahit & 54 & $\mathrm{Rp}$ & 150,000 & & \\
\hline Beban Gaji & 55 & $\mathrm{Rp}$ & $1,350,000$ & $\mathrm{Rp}$ & - \\
\hline TOTAL & & $\mathrm{Rp}$ & $21,201,200$ & $\mathrm{Rp}$ & $21,201,200$ \\
\hline
\end{tabular}

(Sumber : Diolah oleh peneliti 2018)

Batik Jumput Dahlia

Neraca Saldo

Per 31 Desember 2017

\begin{tabular}{|c|c|c|c|}
\hline Nama perkiraan & $\begin{array}{l}\mathrm{Re} \\
\mathrm{f}\end{array}$ & Debit & Kredit \\
\hline Kas & 11 & $\begin{array}{l}\mathrm{Rp} \\
11,125 \\
200\end{array}$ & $\begin{array}{l}\mathrm{Rp} \\
-\end{array}$ \\
\hline Modal & 31 & Rp & $\begin{array}{l}\mathrm{Rp} \\
10,614, \\
200\end{array}$ \\
\hline Penjualan & 41 & Rp & $\begin{array}{l}\mathrm{Rp} \\
6,710,0 \\
00\end{array}$ \\
\hline Beban Pembelian & 50 & $\begin{array}{l}\mathrm{Rp} \\
3,574,0 \\
00\end{array}$ & Rp \\
\hline Beban lain-lain & 51 & $\begin{array}{l}\mathrm{Rp} \\
200,000\end{array}$ & $\mathrm{Rp}$ \\
\hline Beban transport & 52 & $\begin{array}{l}\mathrm{Rp} \\
625,000\end{array}$ & Rp \\
\hline Beban Gaji & 55 & $\begin{array}{l}\mathrm{Rp} \\
1,800,0 \\
00\end{array}$ & $\begin{array}{l}\mathrm{Rp} \\
- \\
\end{array}$ \\
\hline TOTAL & & $\begin{array}{l}\mathrm{Rp} \\
17,324, \\
200\end{array}$ & $\begin{array}{l}\mathrm{Rp} \\
17,324, \\
200\end{array}$ \\
\hline
\end{tabular}

(Sumber : Diolah oleh peneliti 2018) 


\section{Laporan Keuangan}

Laporan Laba Rugi Laporan laba rugi adalah laporan yang memberikan informasi mengenai kinerja keuangan suatu entitas. Dalam SAK EMKM bab 5 menjelaskan bahwa laporan laba rugi entitas terdiri dari pendapatan, beban keuangan dan beban pajak.

Berikut ini adalah laporan laba rugi UMKM Batik Jumput Dahlia yang telah disusun oleh peneliti selama 2 tahun 2016 dan 2017.

\section{Batik Jumput Dahlia}

Laporan Laba Rugi

Untuk Periode yang berakhir 31 Desember 2016

Penjualan

Rp $8,160,000$

Beban Operasional

- Pembelian

$\mathrm{Rp} \quad 2,745,900$

- Beban lain-lain

$\mathrm{Rp} \quad 465,000$

- Beban transport

$\mathrm{Rp} \quad 1,272,000$

- beban Servis

$\mathrm{Rp} \quad 90,000$

- Beban jahit

Rp $\quad 150,000$

- Beban Gaji

$\mathrm{Rp} \quad 1,350,000$

Total Beban Operasional

Rp 6,072,900 +

NETT PROFIT

Rp 2,087,100

(Sumber : Diolah oleh peneliti 2018)

\section{Batik Jumput Dahlia}

Laporan Laba Rugi

Per 31 Desember 2017

Penjualan

Rp 6,710,000

Beban Operasional

- Beban Pembelian Rp 3,574,000

- Beban lain-lain $\quad$ Rp $\quad 200,000$

- Beban transport $\quad \mathrm{Rp} \quad 625,000$ 
- beban Servis

$$
\mathrm{Rp} \quad-
$$

- Beban jahit Rp

- Beban Gaji $\quad$ Rp $1,800,000$

Total Beban Operasional NETT PROFIT

\begin{tabular}{lr} 
Rp & $6,199,000$ \\
\hline Rp 511,000 \\
\hline
\end{tabular}

(Sumber : Diolah oleh peneliti 2018)

\section{Laporan Perubahan Modal}

a. Laporan Perubahan Modal

Perubahan ekuitas atau perubahan modal antara modal awal dan akhir suatu entitas pada suatu periode tertentu menggambarkan naik turunnya asset selama periode berjalan. Berikut ini laporan perubahan modal UMKM Batik Jumput Dahlia.

\section{Batik Jumput Dahlia}

Laporan Perubahan Modal

Untuk Periode yang berakhir 31 Desember 2016

Modal Awal

$+\quad$ Investasi/Setoran Modal

Rp $\quad 13,041,200$

Total

+/- Laba/rugi bersih

Rp 2,087,100

Prive

+/- Kenaikan/Penurunan Modal

Modal Akhir

\begin{tabular}{lr}
$\mathrm{Rp}$ & $2,087,100$ \\
\hline $\mathbf{R p}$ & $\mathbf{1 5 , 1 2 8 , 3 0 0}$ \\
\hline
\end{tabular}

(Sumber : Diolah oleh peneliti 2018)

Batik Jumput Dahlia

Laporan Perubahan Modal

Per 31 Desember 2017

Modal Awal 
$+\quad$ Investasi/Setoran Modal

Total

+/- Laba/rugi bersih

Prive

+/- Kenaikan/Penurunan Modal

Modal Akhir

(Sumber : Diolah oleh peneliti 2018)

\section{Laporan Posisi Keuangan}

Laporan posisi keuangan menyajikan informasi mengenai asset, kewajiban dan ekuitas UMKM Batik Jumput Dahlia. Dalam SAK EMKM Laporan posisi keuangan terdiri dari :

\begin{tabular}{|c|c|c|}
\hline \multicolumn{3}{|c|}{$\begin{array}{c}\text { Laporan Posisi Keuangan } \\
\text { UMKM BATIK JUMPUT } \\
\text { Periode Tahun } 2016 \text { \& } 2017\end{array}$} \\
\hline Keterangan & 2016 & 2017 \\
\hline \multicolumn{3}{|l|}{ ASET } \\
\hline \multicolumn{3}{|c|}{ Kas \& Setara kas } \\
\hline Kas & 15.128 .300 & 11.125 .000 \\
\hline \multicolumn{3}{|l|}{ Giro } \\
\hline \multicolumn{3}{|c|}{ Deposito } \\
\hline \multicolumn{3}{|c|}{ Jumlah Kas \& Setara Kas } \\
\hline \multicolumn{3}{|c|}{ Piutang Usaha } \\
\hline \multicolumn{3}{|c|}{ Persediaan } \\
\hline \multicolumn{3}{|c|}{ beban dibayar dimuka } \\
\hline \multicolumn{3}{|c|}{ Aset tetap } \\
\hline \multicolumn{3}{|c|}{ Akumulasi penyusutan } \\
\hline Jumlah Aset & 15.128.300 & 11.125 .000 \\
\hline \multicolumn{3}{|l|}{ LIABILITAS } \\
\hline \multicolumn{3}{|l|}{ utang usaha } \\
\hline \multicolumn{3}{|l|}{ utang bank } \\
\hline \multicolumn{3}{|c|}{ Jumlah Liabilitas } \\
\hline \multicolumn{3}{|l|}{ EKUITAS } \\
\hline Modal & 13.041 .200 & 10.614 .200 \\
\hline
\end{tabular}


Balance Vol. XVI No. 1| Januari 2019

\begin{tabular}{|l|r|r|} 
Saldo laba & 2.087 .100 & 511.000 \\
\hline Jumlah Ekuitas & 15.128 .300 & 11.125 .200 \\
\hline & & \\
\hline Jumlah Liabilitas \& Ekuitas & $\mathbf{1 5 . 1 2 8 . 3 0 0}$ & $\mathbf{1 1 . 1 2 5 . 2 0 0}$ \\
\hline
\end{tabular}

\section{Catatan Atas Laporan Keuangan}

1. Umum

Batik Jumput UMKM DAHLIA Surabaya merupakan usaha yang terdiri dari Ibu - Ibu PKK berdiri sejak tahun 2013 dan sudah berjalan selama 5 tahun lamanya, berlokasi di wilayah Surabaya Selatan tempatnya di Kelurahan Ngagel Surabaya. Entitas bergerak dalam bidang usaha jasa

2. Ikhtisar Kebijakan Akuntansi

a. Pernyataan Kepatuhan

Laporan keuangan disusun menggunakan Standart Akuntansi Keuangan Entitas Mikro, Kecil dan Menengah.UMKM Batik Jumput Dahlia merupakan tergolong usaha Mikro dengan omset pertahun rata-rata sebesar Rp 22.500.000

b. Dasar Penyusunan

Dasar penyusunan laporan keuangan menggunakan biaya historis dan menggunakan asumsi dasar akrual. Mata uang digunakan adalah Rupiah.

c. Aset Tetap

Aset tetap dicatat sebesar biaya perolehannya jika asset tersebut dimiliki secara hukum oleh entitas. Aset tetap disusutkan menggunakan metode garis lurus tanpa nilai residu.

d. Pengakuan Pendapatan dan Beban

Pendapatan diakui secara tunai pada saat terima order oleh beban dan beban diakui saat terjadi.

e. Kas merupakan kas ditangan ditahun 2016 sebesar Rp 15.128.300 dan ditahun 2017 sebesar Rp 11.125.200

f. Modal Usaha tahun 2016 sebesar Rp 13.041.200 dan tahun 2017 sebesar Rp 10.614.200 g. Saldo laba tahun 2016 sebesar Rp 2.087.100 dan laba tahun 2017 sebesar Rp 511.000

h. Pendapatan penjualan tahun 2016 sebesar Rp 8.160.000 dan penjualan di tahun 2017 sebesar Rp 6.710.000

\section{SIMPULAN, SARAN DAN KETERBATASAN PENELITIAN \\ Simpulan}

1. Tidak adanya laporan keuangan pada UMKM Batik Jumput Dahlia, belum mampu menyusun laporan keuangan berdasarkan standar akuntansi yang berlaku untuk EMKM. Hal ini dilihat dari bukti pencatatan yang dilakukan yakni hanya mencatat keluar masuknya kas, serta tidak mencatat seluruh aset yang dimiliki. Keadaan yang seperti ini mengakibatkan UMKM Batik Jumput Dahlia tidak mampu mengetahui segala macam kegiatan yang bisa mempengaruhi berkurang dan bertambahnya nilai suatu aset yang dimiliki, jumlah kewajiban yang harus dibayar serta total modal yang dimiliki.

2. Bukti-bukti transaksi yang terjadi selama periode tertentu tidak diarsipkan maupun dicatat keseluruhannya hal ini mengakibatkan kesulitan dalam penyusunan.

\section{Saran}

1. Diharapkan UMKM Batik Jumput Dahlia melakukan penyusunan laporan keuangan berdasarkan ketentuan yang berlaku yakni menggunakan SAK EMKM. Hal ini bertujuan agar UMKM 
Balance Vol. XVI No. 1 | Januari 2019

Batik Jumput Dahlia mampu mengetahui informasi secara lengkap mengenai seluruh aset yang dimiliki. Selain itu dengan melakukan penyusunan laporan keuangan yang berbasis SAK EMKM dikemudian hari.

2. UMKM Batik Jumput Dahlia sebaiknya mengarsipkan semua bukti transaksi dan melakukan pencatatan yang rutin, hal ini bertujuan memudahkan dalam penyusunan laporan keuangan.

3. Perlu direkrutnya SDM yang berkompeten dibidang akuntansi untuk membantu menyusun laporan keuangan serta diikutkan pelatihan pembukuan secara rutin.

\section{DAFTAR PUSTAKA / BIBLIOGRAPHY}

Amirin, Tatang M. 2000. Menyusun Rencana Penelitian. Jakarta: Raja Grafindo Persada.

Harahap, Sofyan Syafri. 2009. "Analisis Kritis Atas Laporan Keuangan". Jakarta: RajaGrafindo Persada.

Hery. 2012. Akuntansi Keuangan Menengah 1. Jakarta: Bumi Aksara.

Horrison Jr., Walter T., et al. 2012. Akuntansi Keuangan IFRS Edisi Kedelapan. Jakarta: Erlangga.
Ikatan Akuntan Indonesia. 2012. Standar Akuntansi Keuangan. Jakarta: IAI

Ikatan Akuntan Indonesia. 2009. Standar Akuntansi Keuangan per 1 Juli 2009. Jakarta : Salemba Empa.

Ikatan Akuntan Indonesia. 2018. Standar Akuntansi Entitas Mikro Kecil dan Menengah. Jakarta : IAI

Kartikahadi, H et al. 2012. Akuntansi Keuangan Berdasarkan SAK Berbasis IFRS. Jakarta: Salemba Empat.

Kasmir. 2013. Analisis Laporan Keuangan. Rajawali Pers : Jakarta.

Marisi P. Purba. 2010. International Financial Reporting Standards Konvergensidan Kendala Aplikasinya di Indonesia. Yogyakarta : Graha Ilmu.

Mulyadi. 2001. Sistem Akuntansi. Jakarta: Salemba Empat.

Munawir, S. 2004. Analisis Laporan Keuangan. Yogyakarta:Liberty.

Nana Syaodih Sukmadinata. 2011. Metode Penelitian Pendidikan. Bandung: Remaja Rosdakarya.I

UU Nomor 20 Tahun 2008 tentang UMKM 